Acta vet. scand. 1984, 25, 187-194.

From the Department of Internal Medicine I, Division of Parasitology, Norwegian College of Veterinary Medicine, Oslo and the National Veterinary Institute, Oslo.

\title{
THE DOMESTIC REINDEER (RANGIFER TARANDUS) FROM NORTHERN NORWAY AS INTERMEDIATE HOST FOR THREE SPECIES OF SARCOCYSTIS
}

\author{
By \\ Bjorn Gjerde and Bjørn Bratberg
}

\begin{abstract}
GJERDE, B. and B. BRATBERG: The domestic reindeer (Rangifer tarandus) from northern Norway as intermediate host for three species of Sarcocystis. Acta vet. scand. 1984, 25, 187-194. - Sections of skeletal and cardiac muscle of reindeer from northern Norway were examined for sarcocysts by light microscopy. In skeletal muscle 3 different types of cysts were demonstrated; thick-walled macroscopic cysts surrounded by a fibrillar layer (Type 1), thick-walled microscopic cysts (Type 2) and thin-walled microscopic cysts (Type 3). In cardiac muscle only thin-walled cysts of type 3 were found. The 3 different types of cysts are considered to be cysts of 3 different species of Sarcocystis infecting the reindeer.

Dogs and foxes fed muscular tissue from reindeer started shedding Sarcocystis sporocysts measuring $13.9 \times 10.2 \mu \mathrm{m}$ and $14.4 \times 10.4 \mu \mathrm{m}$, respectively, after a prepatent period of $11-17$ days. Dogs and foxes are considered to be definitive hosts for Sarcocystis sp. with type 3cysts. The original descriptions of Sarcocystis grueneri are critically reviewed and found to be inadequate. By comparing the size, cyst wall morphology and location of the cysts in the present investigation with those of the original papers, it is found that Sarcocystis sp. with type 3 -cysts in all likelihood is identical with Sarcocystis grueneri. The name Sarcocystis grueneri is retained and assigned to the Sarcocystis sp. with type 3-cysts in cardiac and skeletal muscle of reindeer.

The dog (Canis familiaris), the silver fox (Vulpes vulnes) and the blue fox (Alopex lagopus) are recorded as definitive hosts for Sarcocystis grueneri.
\end{abstract}

Sarcocystis grueneri; life cycle; definitive hosts; dog; silver fox; blue fox.

Coccidians belonging to the genus Sarcocystis have an obligatory two-host life cycle with herbivores as intermediate hosts and carnivores and man as definitive hosts. A Sarcocystis infection 
is recognized by demonstrating cysts in striated muscle of the intermediate host and sporocysts in the faeces of the definitive host.

The occurrence of sarcocysts in reindeer was reported for the first time by Bergman (1913) in Sweden, and later by Hadwen (1922) in Alaska, Grüner (1927) in Russia and by Skjфlaas (1970) in Norway. One species, i.e. Sarcocystis grueneri Yakimoff $\&$ Sokoloff, 1934, has been known to infect the reindeer. However, an adequate description of the sarcocysts of this species has not been available and its definitive host has not been known (Levine \& Tadros 1980).

The present investigation was undertaken to study the morphology of sarcocysts in Norwegian reindeer, to establish their relationship with Sarcocystis grueneri and their infectivity for dogs and foxes.

\section{MATERIAL AND METHODS}

Specimens of cardiac or skeletal muscle (mainly from the thorax and abdomen) were obtained from 6 adult reindeer slaughtered at abattoirs in Kautokeino and Karasjok, Finnmark county, Norway. The skeletal muscle samples contained numerous macroscopically visible sarcocysts, while no cysts were seen in cardiac muscle by gross examination.

Specimens of muscular tissue were selected for histological examination, fixed in $\mathbf{1 0} \%$ neutral buffered formalin, processed routinely, sectioned at 5-6 $\mu \mathrm{m}$ and stained with haematoxylin and eosin (HE), periodic acid Schiff (PAS) and silver impregnation technique (Wilder).

Muscular tissue kept refrigerated for not more than 2 days after slaughter and micro-isolated macroscopic cysts from skeletal muscle were used for experimental infection of dogs (Canis familiaris), silver foxes (Vulpes vulpes) and blue foxes (Alopex lagopus). Each carnivore was given $0.3-0.5 \mathrm{~kg}$ of muscular tissue in a single feeding, or about 100 micro-isolated macroscopic cysts either by stomach tube or mixed with the ordinary food. Muscular tissue from 1 or 2 reindeer was used in each of 4 separate experiments. The experimental design is shown in Table 1.

The carnivores had been conventionally reared, but had never eaten raw meat before. The dogs were 6 weeks or older, and the 
T a b l e 1. Experimental design.

\begin{tabular}{|c|c|c|}
\hline Exp. no. & Tissue fed to dogs/foxes & Number of dogs/foxes fed \\
\hline 1 & $\begin{array}{l}\text { Skeletal muscle } \\
\text { None }\end{array}$ & $\begin{array}{l}2 \text { silver foxes, } 2 \text { blue foxes, } 2 \text { dogs } \\
1 \text { silver fox, } 1 \text { blue fox, } 1 \text { dog }\end{array}$ \\
\hline 2 & $\begin{array}{l}\text { Skeletal muscle } \\
\text { Micro-isolated macrocysts } \\
\text { None }\end{array}$ & $\begin{array}{l}1 \text { silver fox, } 1 \text { blue fox } \\
1 \text { silver fox, } 1 \text { blue fox } \\
1 \text { silver fox, } 1 \text { blue fox }\end{array}$ \\
\hline 3 & $\begin{array}{l}\text { Skeletal muscle } \\
\text { Cardiac muscle } \\
\text { Micro-isolated macrocysts } \\
\text { Skeletal and cardiac } \\
\text { muscle } \\
\text { None }\end{array}$ & $\begin{array}{l}1 \text { silver fox, } 1 \text { blue fox } \\
1 \text { silver fox, } 1 \text { blue fox } \\
1 \text { silver fox, } 1 \text { blue fox, } 1 \mathrm{dog} \\
2 \text { dogs } \\
1 \text { dog }\end{array}$ \\
\hline 4 & Skeletal muscle & 1 silver fox, 1 blue fox, 2 dogs \\
\hline
\end{tabular}

foxes 6 months or older. They were caged individually and their faeces were collected daily for 4-10 weeks and examined for coccidian parasites after flotation with a saturated salt solution. The carnivores were coccidia-free at the start of the experiments. The size of sarcocysts and sporocysts was measured with an ocular micrometer.

\section{RESULTS}

Light microscopic examination of muscular tissue

Examination by light microscopy of sections from skeletal and cardiac muscle revealed 3 different types of sarcocysts; one type of thin-walled cysts found both in cardiac and skeletal muscle, and two types of thick-walled cysts found only in skeletal muscle. The cysts studied were mature cysts containing predominantly cystozoites (merozoites), with only a few metrocytes lying peripherally in the cysts. From the stained sections the different cyst types can be described as follows:

Ty p e 1-c y s t s (F i g. 1): Thick-walled, macroscopic cysts (measuring on average $2.4 \times 0.5 \mathrm{~mm}$ in fresh preparations $(n=25))$. The cyst wall $10-12 \mu \mathrm{m}$ thick and radially striated, striations lying 5-6 $\mu \mathrm{m}$ apart, giving the cyst wall a palisadelike appearance. The cyst surrounded by a $4-5 \mu \mathrm{m}$ thick PASpositive fibrillar layer. The interior of the cyst divided into chambers by rather conspicuous septa. The cysts found in skeletal muscle only. 
Ty pe 2-c y s ts (F i g. 2): Thick-walled, microscopic cysts measuring on average $384 \times 76 \mu \mathrm{m}$ in sections $(n=15)$. The cyst wall 7-9 $\mu \mathrm{m}$ thick and radially striated. The striations lying closer together than in the type 1-cysts, giving the wall a hairy appearance in sections. No fibrillar layer surrounding the cyst. Indistinct septa. The cysts found in skeletal muscle only.

Ty pe 3-c y t s (F i g. 3 a): Thin-walled, microscopic cysts measuring on average $346 \times 93 \mu \mathrm{m}$ in sections $(n=15)$. The cyst wall $1-2 \mu \mathrm{m}$ thick. No fibrillar layer surrounding the cyst. Indistinct septa. Cysts found in both cardiac and skeletal muscle, but with the heart most heavily infected as judged from the number of cysts found in sections.

\section{Experimental infection of dogs and foxes}

None of the uninfected control animals and none of the animals given micro-isolated macroscopic cysts shed any oocysts or sporocysts during the experiments.

All the foxes, but none of the dogs, that had been given muscular tissue in Exp.nos. 1, 2 and 4, shed small, unsporulated Hammondia heydorni-like oocysts for 6-23 days after a prepatent period of 7 days. The oocysts averaged $12.5 \times 11.1 \mu \mathrm{m}$ in size and have been described in more detail in another paper (Gjerde 1983).

Eleven out of 12 foxes and 4 out of 6 dogs given muscular tissue started shedding sporulated sporocysts after a prepatent period of 11-17 days (Table 2).

Table 2. Shedding of Sarcocystis sporocysts by dogs and foxes fed muscular tissue of reindeer.

\begin{tabular}{cllcc}
\hline Exp. no. & $\begin{array}{c}\text { Muscular } \\
\text { tissue }\end{array}$ & $\begin{array}{c}\text { Infective } \\
\text { for }\end{array}$ & $\begin{array}{c}\text { Prepatent } \\
\text { period (days) }\end{array}$ & $\begin{array}{c}\text { Sporocyst size } \\
(\mu \mathrm{m})\end{array}$ \\
\hline \multirow{2}{*}{$\begin{array}{l}\text { Skeletal } \\
2\end{array}$} & 4 foxes & $14-16$ & $14.6 \times 10.8$ \\
3 & Skeletal & 1 fox & 17 & $13.6 \times 10.5$ \\
& Skeletal & 2 foxes & 14 & $15.2 \times 10.6$ \\
& Cardiac & 2 foxes & 11 & $13.7 \times 10.2$ \\
& Skeletal \& & 2 dogs & 11 & $14.0 \times 10.4$ \\
4 & cardiac & & & \\
& Skeletal & 2 foxes & 17 & $14.4 \times 10.1$ \\
& Skeletal & 2 dogs & $16-17$ & $13.3 \times 10.0$ \\
\hline
\end{tabular}



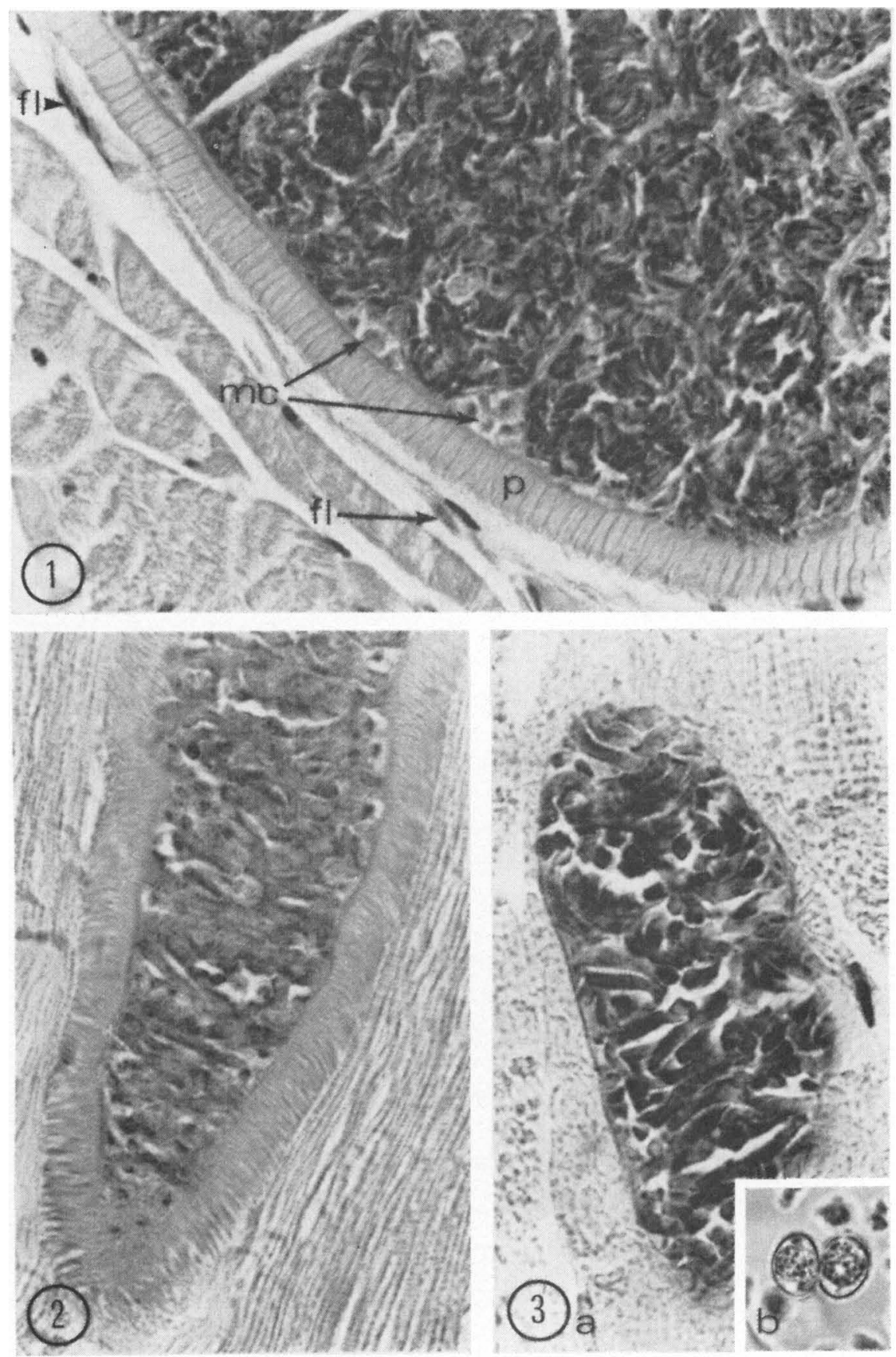

Figur e 1. Sarcocystis sp. with type 1-cyst in skeletal muscle. Thick, radially striated palisade-like cyst wall (p). Fibrillar layer (fl) surrounding the cyst. Metrocytes (mc) peripherally in cyst. H.E. $\times 500$.

Figure 2. Sarcocystis sp. with type 2-cyst in skeletal muscle. Thick, radially striated hair-like cyst wall. H.E. $\times \mathbf{8 0 0}$.

F i g u r e 3. Sarcocystis sp. with type 3-cyst.

(a) Thin-walled cyst in cardiac muscle. H.E. $\times 800$.

(b) Oocyst in the faeces of a fox. Fresh preparation $\times 680$. 
In Exp.no. 1 sporocysts were shed for 56 days (faeces examined for 68 days after infection), and in Exp.nos. 2, 3 and 4 sporocysts were still being shed when the experiments ended on days 33,26 and 24, respectively, after infection.

The sporocysts were fully sporulated when shed, and each contained 4 sporozoites and a sporocystic residual body consisting of coarse granules. On the first days of patency a few thinwalled oocysts containing 2 sporocysts each were also seen (Fig. 3b).

The sporocysts shed by the foxes that had been given skeletal muscle measured $13.4-16.2(14.8 \pm 0.8) \times 9.4-12.2(10.5 \pm 0.5)$ $\mu \mathrm{m}(\mathrm{n}=59)$, while the sporocysts shed by foxes that had been given cardiac muscle in Exp.no. 3 measured 11.7-14.8 (13.7 \pm $0.6) \times 9.2-10.8(10.2 \pm 0.4 \mu \mathrm{m}(\mathrm{n}=35)$. The sporocysts shed by foxes in all experiments averaged $14.4 \times 10.4 \mu \mathrm{m}$ in size. The sporocysts shed by the dogs in Exp.nos. 3 and 4 after ingestion of cardiac and skeletal muscle measured 12.3-15.5 (13.9 \pm 0.9$)$ $\times 9.6-10.7(10.2 \pm 0.4) \mu \mathrm{m}(\mathrm{n}=17)$.

\section{DISCUSSION}

The sarcocysts studied in the present investigation were mature cysts. Thus, the differences described in cyst size and cyst wall morphology between the 3 types, do not merely reflect different developmental stages of cysts of a single species, but show that the reindeer is intermediate host for 3 different species of Sarcocystis. Previously, only one species, i.e. Sarcocystis grueneri has been known from reindeer.

The name Sarcocystis grueneri was introduced by Yakimoff \& Sokoloff (1934) for the "sarcocysts" (Sarkozysten) described by them in reindeer and maral (Cervus canadensis asiaticus). However, in their paper the term "sarcocysts" is used not to denominate the muscle cysts, but rather the individual organisms within the cysts (i.e. the spores = cystozoites, merozoites) and the organisms as a group (synonymous with "Sarcosporidia"). Thus, misinterpretations may easily arise unless the paper is carefully read.

Yakimoff \& Sokoloff (1934) give no description of muscle cysts in reindeer, they merely report the findings of Bergman (1913), Hadwen (1922) and Grüner (1927) and present pictures of the cysts found by Grüner (1927) in cardiac muscle of reindeer. Yakimoff $\&$ Sokoloff themselves made smears from a piece 
of cardiac muscle of a reindeer and the blood in the heart of a maral. In the smears from both animals they found organisms that they thought were "spores" of Sarcocystis. The nature of these spores is uncertain, especially of those found in the blood smears from the maral. The measured size and the shape (from a drawing) are consistent with those of sarcosporidian cystozoites, but no cysts were observed.

The authors believed that cattle, buffalo, reindeer and maral were infected with the same species of Sarcocystis, having a different name in each host. When present in reindeer and maral, spores of this species was named Sarcocystis grüneri (S. grueneri).

In another paper on sarcosporidia of reindeer Yakimoff (1936) gives his own description of both cysts and cystozoites, naming the last-mentioned Sarcocystis grüneri. The cysts were found in both cardiac and skeletal muscle of reindeer. He described the cysts from skeletal muscle as being whitish, elongate structures with 2 pointed ends. The cysts had septa ( $Z_{w i-}$ schenwände) and contained numerous banana-shaped cystozoites (Sporozoiten). Drawings of an entire cyst and of a part of a cyst give the impression of a thin, non-striated cyst wall and a marked compartmentation of the cyst. The cysts measured 150-211 $\times$ $57-96 \mu \mathrm{m}$ in sections from cardiac muscle and $163-298 \times 52-$ $81 \mu \mathrm{m}$ in fresh preparations from a muscle on the hind limb.

Since the publishing of these 2 papers, the name Sarcocystis grueneri has been used to designate the species of Sarcocystis infecting reindeer, but a more detailed description of its cysts and life cycle has, as far as we know, not been given.

From the original description of Sarcocystis grueneri (Yakimoff \& Sokoloff 1934) it would be impossible to identify the species today. However, when the description of Yakimoff (1936) is used in addition, one can arrive at a fairly reliable conclusion as regards the relationship between Sarcocystis grueneri and the Sarcocystis spp. of the present investigation. According to Yakimoff (1936) Sarcocystis grueneri had small, relatively thinwalled cysts in both cardiac and skeletal muscle. Only the type 3 -cysts of the present investigation meet these requirements, strongly indicating that the species with type 3-cysts is identical with Sarcocystis grueneri. We therefore assign the name Sarcocystis grueneri to the species described in the present paper as having type 3-cysts in cardiac and skeletal muscle of reindeer. 
Two foxes fed cardiac muscle infected with only type 3-cysts and 2 dogs fed a mixture of cardiac and skeletal muscle started shedding sporocysts after the same prepatent period of 11 days, indicating that the Sarcocystis sp. with type 3-cysts had completed its life cycle in both foxes and dogs. It is possible that more than one of the species found in reindeer have dogs and foxes as definitive hosts, but this cannot be conclusively determined from the present experiments. The failure of dogs and foxes to shed sporocysts when fed micro-isolated cysts of type 1, indicates that these carnivores are not suitable definitive hosts for this species. The longer prepatent period of 14-17 days found when skeletal muscle was fed, might reflect a lighter infection of the carnivores, consistent with the finding of fewer type 3-cysts in skeletal than in cardiac muscle. A light infection with the shedding of few sporocysts early in patency might not be detected, giving the impression of a longer prepatent period. Thus, we consider the sporocysts shed by dogs and foxes in the present investigation to be sporocysts of Sarcocystis grueneri only, establishing the dog, the silver fox and the blue fox as definitive hosts for this species.

As far as we know, this is the first experimental completion of the life cycle of Sarcocystis grueneri in dogs and foxes. Under natural conditions in Finnmark it is likely that, in addition to dogs, red foxes (Vulpes vulpes) and arctic foxes (Alopex lagopus), of which the silver fox and the blue fox, respectively, are colour mutants, act as definitive hosts for Sarcocystis grueneri.

As regards the Sarcocystis sp. with type 1-cysts and the Sarcocystis sp. with type 2-cysts, further experiments are needed to elucidate their life cycles and establish their definitive hosts.

\section{AGKNOWLEDGEMENTS}

The authors would like to thank K. Kummeneje and K. Korbi for their sampling of the material from reindeer used in this investigation.

\section{REFERENCES}

Bergman, A. M.: Beitrag zur Kenntnis des Vorkommens der Sarkosporidien bei den Haustieren. (Occurrence of Sarcosporidia in domestic animals). Z. Fleisch. Milchhyg. 1913, 23, 169-180.

Gjerde, B.: Shedding of Hammondia heydorni-like oocysts by foxes fed muscular tissue of reindeer (Rangifer tarandus). Acta vet. scand. $1983,24,241-243$.

Grüner, S. A.: (Sarcosporidiosis of reindeer). [Russ. text]. Vet. Trushenik 1927, 3, No. 9-10, 27-30.

Hadwen, S.: Cyst-forming protozoa in reindeer and caribou, and a sarcosporidian parasite of the seal (Phoca richardi). J. Amer. vet. med. Ass. 1922, 61, 374-382. 
Levine, N. D. \& W. Tadros: Named species and hosts of Sarcocystis (Protozoa: Apicomplexa: Sarcocystidae). Syst. Parasitol. 1980, $2,41-59$.

Skjølaas, O.: Sarcosporidier i reinkjøtt i Kautokeino-området. (Sarcosporidia in reindeer meat in the Kautokeino-area). Norsk Vet.tidsskr. 1970, 82, 264-265.

Yakimoff, W. L.: Zur Frage der Sarkozysten der Rentiere. (Sarcocystosis in reindeer). Z. Infekt.-Kr. Haustiere 1936, 50, 217223.

Yakimoff, W. L. \& I. I. Sokoloff: Die Sarkozysten des Renntieres und des Maral (Sarcocystis grüneri n. sp.). (Sarcocysts of the reindeer and maral). Berl. tierärztl. Wschr. 1934, 50, 772-774.

\section{SAMANDRAG}

Tamrein frå Nord-Noreg som mellomvert for tre arter av Sarcocystis.

Skjelett- og hjertemuskulatur av rein frå Finnmark vart unders $\varnothing$ kt for sarcocyster. I lysmikroskopiske snitt av skjelettmuskulatur fann ein 3 ulike cystetypar som representerer cyster av 3 ulike Sarcocystisarter.

Type 1-cystene var tjukkveggja, makroskopisk synlege cyster med ein $10-12 \mu \mathrm{m}$ tjukk cystevegg med radiære stripningar omgjeven av eit 4-5 $\mu \mathrm{m}$ tjukt PAS-positivt fibrillært lag. Type 2-cystene var tjukkveggja, små cyster med ein $7-9 \mu \mathrm{m}$ tjukk vegg med radiære stripningar. Stripningane tettare enn hos type 1-cystene. Type 3-cystene var tunnveggja, små cyster med ein $1-2 \mu \mathrm{m}$ tjukk cystevegg. I hjertemuskulatur fann ein berre type 3-cyster.

I 4 separate fors $\varnothing \mathbf{k}$ fekk 12 revar og 6 hundar fersk skjelett- og/ eller hjertemuskulatur med sarcocyster. Etter ein prepatentperiode på 11 - 17 dagar tok 11 revar og 4 hundar til med å skilja ut Sarcocystissporocyster av storleik $14.4 \times 10.4 \mu \mathrm{m}$ (rev) og $13.9 \times 10.2 \mu \mathrm{m}$ (hund). Det vert konkludert med at hund og rev er endevertar for den Sarcocystis-arta som har type 3-cyster i hjerte- og skjelettmuskulatur hos rein.

Ved kritisk gjennomgang av originalartiklane der namnet Sarcocystis grueneri vart introdusert, finn ein at cystene til denne arta er ufullstendig definert. Ein finn likevel gode haldepunkt for at Sarcocystis grueneri er identisk med Sarcocystis sp. med type 3-cyster. Namnet Sarcocystis grueneri vert difor nytta om denne arta hos rein med hund og rev som endevertar.

(Received January 16, 1984).

Addendum added at the proof reading

Later investigations employing other methods have shown that the Sarcocystis sp. with type 3-cyst described in the present paper comprises 2 species, parasitizing cardiac and skeletal muscle, respectively. The name S. grueneri has been confined to the species with thin-walled cysts in cardiac muscle.

Reprints may be requested from: B. Gjerde, the Norwegian College of Veterinary Medicine, Box 8146, Dep., N-0033 Oslo 1, Norway. 